\title{
High-fat Diet Induced Dysbiosis \& Amelioration by Astaxanthin
}

\author{
Kyle Haasbroek ${ }^{1}$, Wakako Takabe ${ }^{1}$, Masayuki Yagi ${ }^{1}$, Yoshikazu Yonei ${ }^{1}$ \\ ${ }^{1}$ Anti-Aging Medical Research Center and Glycation Stress Research Center, \\ Graduate School of Life and Medical Sciences, Doshisha University, Japan
}

\section{ABSTRACT:}

Astaxanthin is a carotenoid that is present in high quantities in the meat of fish like salmon and the shells of shrimp and crab. It exhibits free radical scavenging antioxidant activity when consumed dietarily. Astaxanthin is absorbed by the small intestine before exerting its antioxidant effect; however, a portion of dietary intake remains unabsorbed in the digestive tract and reaches the large intestines. We hypothesized that astaxanthin may exert its antioxidant action in the large intestine to influence the gut microbiota. In this review we introduce the results of two studies of astaxanthin. Firstly, a clinical trial targeting post-menopausal women screened for high oxidative stress burden. Astaxanthin was administered orally for eight weeks in order to examine its effects and safety, and subjects were surveyed for any changes in subjective symptoms. Secondly, in a mouse model, real time PCR (polymerase chain reaction) was used to examine the ability of astaxanthin to prevent changes in the enteric flora induced by a high-fat diet. When fat intake increases due to changes in diet, the equilibrium between the various species that constitute the intestinal flora is altered. As a result, degenerative changes in lifestyle-related disease and aging of the host are promoted. Here we find that the intake of astaxanthin was able to inhibit these changes in the gut microbiota of mice induced by a high-fat diet. Even in humans, it is highly probably that the unabsorbed astaxanthin that remains in the intestinal tract exerts a positive effect against disturbance of the intestinal flora caused by a high-fat diet.

KeYwORDS: Astaxanthin; Gut microbiota; Antioxidant; High fat diet; Dysbiosis

\section{SAŽETAK:}

Disbioza inducirana dijetom bogatom Mastima \& AmElioracija pomoću astaKsantina Astaksantin je karotenoid prisutan u velikom količinama u mesu riba poput lososa i oklopima kozica i rakova. Kada se uzima kao hrana ispoljava svoju sposobnost hvatanja slobodnih radikala i antioksidativnog djelovanja. Prije no što započne svoje antioksidativno djelovanje apsorbira se preko tankog crijeva, međutim, dio ostaje neapsorbiran i dospijeva u debelo crijevo. Razmatrali smo mogućnost da astaksantin pomoću svojih antioksidativnih svojstava može utjecati na crijevnu mikrobiotu. U okviru ovog preglednog rada osvrnut ćemo se na rezultate dvaju istraživanja. Prvo je kliničko ispitivanje usmjereno na postmenopauzalne žene koje su prošle screening na opterećenost oksidativnim stresom. Astaksantin su dobivale oralno kroz 8 tjedana kako bi se procijenili njegovi učinci i sigurnost, a ispitanice su anketirane vezano za promjene u subjektivnim simptomima. Drugi, mišji model, koristio je PCR (Lančanu reakciju polimeraze) u pravom vremenu kako bi ispitao potencijal astaksantina u sprječavanju promjena u crijevnoj flori induciranih dijetom bogatom mastima. Pri dijeti bogatoj mastima povećava se unos masti što narušava ravnotežu raznih vrsta koje sačinjavaju intestinalnu floru. Posljedična neravnoteža rezultira degenerativnim promjenama i bolestima vezanima za način života. U ovom istraživanju nalazimo da unos astaksantina može spriječiti promjena u mikrobioti miševa izazvane prehranom bogatom mastima. Čak i u ljudi je za vjerovati da neapsorbirani astaksantin koji ostaje u debelom crijevu ima pozitivan učinak protiv poremećaja uzrokovanih prehranom bogatom mastima.

KLJUČnE RIJEČI: Astaksantin; Crijevna mikrobiota; Antioksidans; Prehrana bogata mastima; Disbioza

\section{OPEN ACCESS}

\section{Correspondence:} Yoshikazu Yonei

yyonei@mail.doshisha.ac.jp orcid.org/0000-0002-2682-752X

This article was submitted to RAD CASA - Medical Sciences as the Original Article

Conflict of Interest Statement: The authors declare that the research was conducted in the absence of any commercial or financial relationships that could be construed as a potential conflict of interest.

Received: 17 October 2019 Accepted: 24 November 2019 Published: 17 December 2019

\section{Citation:}

Haasbroek K, Takabe W, Yagi M and Yoshikazu Y. High-fat diet induced dysbiosis \& amelioration by astaxanthin RAD CASA - Medical Sciences. $540=48-49$ (2019): 58-66. https:// $540=48-49$ (2019): 58-66. https:
dx.doi.org/10.21857/9xn31crexy

Copyright (C) 2019 Haasbroek, Takabe, Yagi and Yoshikazu. Franceschi, Buljan and Situm. This is an open-access article distributed under the terms of the Creative Commons Attribution License (CC BY). The use, distribution or reproduction in other forums is permitted, provided the original author(s) and the copyright owners(s) are credited and that the
original publication in this journal is original publication in this journal is
cited, in accordance whit accepted adacemic practice. No use, distribution or reproduction is permitted which does not comply with these terms. 
Table 1. Symptom Scores from Anti-Aging QOL Common Questionnaire

\begin{tabular}{|ccc|}
\hline & Baseline & Week 8 \\
\hline (Physical Symptoms) & & \\
Eye Fatigue & $3.1 \pm 0.8$ & $2.4 \pm 0.8 * *$ \\
Stiff Shoulders & $3.4 \pm 1.0$ & $2.9 \pm 1.1 * *$ \\
Weight Gain & $2.9 \pm 1.4$ & $2.5 \pm 1.4 *$ \\
Skin Problems & $2.5 \pm 0.8$ & $2.1 \pm 0.8 * *$ \\
Constipation & $2.4 \pm 1.2$ & $2.0 \pm 1.0 *$ \\
Hair Loss & $2.3 \pm 0.9$ & $1.9 \pm 0.8 *$ \\
Gray Hair & $3.6 \pm 0.9$ & $3.1 \pm 0.9 *$ \\
Cold Sensitivity & $2.8 \pm 1.0$ & $2.3 \pm 1.1 * *$ \\
Dsychological Symptoms) & $2.1 \pm 0.89$ & \\
Difficulty Falling Asleep & $1.8 \pm 0.8 *$ \\
\hline Symptom Score: 1 not at all, 2 a little, 3 moderately, 4 quite a lot, 5 very much. \\
${ }^{*} p<0.05, * * p<0.01$ vs. baseline score, paired t-test. Cited from reference 5). \\
\hline
\end{tabular}

\section{INTRODUCTION}

Astaxanthin is a carotenoid that is present in high quantities in the meat of fish like salmon and the shells of shrimp and $\mathrm{crab}^{1}$. It has attracted much attention in the field of preventative medicine for its effects against various lifestyle-related illnesses, its anti-fatigue action, and general health improving properties ${ }^{2}$. Astaxanthin is also garnering attention as an ingredient in supplements, for which it is naturally produced by the microalgae Haematococcus pluvialis. Astaxanthin exhibits free radical scavenging antioxidant activity when consumed dietarily ${ }^{3,4}$. Previously we performed an open-label non-controlled study examining the safety and efficacy of eight-week oral astaxanthin intake in post-menopausal women with high oxidative stress burden, demonstrating increased antioxidant capacity, lower blood pressure, and improvement of constipation and menopause symptoms $s^{5}$. Astaxanthin is absorbed by the small intestine before exerting its antioxidant effect; however, a portion of dietary intake remains unabsorbed in the digestive tract and reaches the large intestines ${ }^{6-8}$. We hypothesized that astaxanthin may exert its antioxidant action in the large intestine to influence the gut microbiota (enteric flora), and are continuing research into the phenomenon.

The enteric flora changes with age and lifestyle/environment ${ }^{9,10}$, and is associated with overall health and the incidence of carcinogenesis. Every individual's intestinal tract is inhabited by a characteristic ecosystem of bacteria that collectively forms the gut microbiome. Normally there is equilibrium between the gut microbiota and host, as well as between bacterial species. When this balance is disrupted, dysbiosis ${ }^{11}$ and opportunistic infections occur, greatly influencing aging $^{12}$, nutrition ${ }^{13}$, the efficacy of medication ${ }^{14,15}$, physiological function $^{16}$, immune function ${ }^{17}$, and carcinogenesis ${ }^{18-20}$ of the host.

In this review we introduce the results of two studies of astaxanthin. Firstly, a clinical trial ${ }^{5}$ targeting post-menopausal women screened for high oxidative stress burden. Astaxanthin was administered orally for eight weeks in order to examine its effects and safety, and subjects were surveyed for any changes in subjective symptoms. Secondly, in a mouse model, real time PCR (polymerase chain reaction) ${ }^{21-23}$ was used to examine the ability of astaxanthin to prevent changes in the enteric flora induced by a high-fat $\operatorname{diet}^{24}$.

\section{Clinical Study Methods}

In this study, participants were screened in order to select those with high oxidative stress. The screening test measured diacron-reactive oxygen metabolites (d-ROM) as an indicator of the intensity of oxidative stress burden. From an initial group of 35 healthy post-menopausal women $(\mathrm{d}-\mathrm{ROM}=362.3 \pm 51.4$ CARR U), 14 with low $\mathrm{d}$-ROM scores were excluded, and the remaining group of 21 participants ( $\mathrm{d}-\mathrm{ROM}=387.4 \pm 32.4 \mathrm{CARR} \mathrm{U})$ with high oxidative stress burden comprised the participants of this study. Participants took two $6 \mathrm{mg}$ astaxanthin soft capsules ([AstaReal ACT] Fuji Chemical Industry Co.) per day for 8 weeks.

For the evaluation, symptoms were divided into "physical symptoms" and "psychological symptoms" in the Anti-Aging QOL Common Questionnaire 25). Participants were asked to rank their severity on a scale of one to five.

Of the 34 surveyed physical symptoms, eight symptoms significantly improved after 8 weeks of taking the supplement: "eye fatigue," "stiff shoulders," "weight gain," "skin problems," "constipation," "hair loss," "grey hair," and "cold sensitivity" (Table 1). Of 21 psychological symptoms, "difficulty falling asleep" improved significantly after 8 weeks. There was no significant change in the lifestyle habits of the participants.

Improving "constipation" is one of the known benefits of astaxanthin, and is commonly reported in post marketing surveillance. Astaxanthin also relieves loose stool and diarrhea associated with abnormal intestinal fermentation. Its bioavailability is low at $2-5 \%$, with the greater majority remaining and acting within the digestive tract. Astaxanthin may be exerting antioxidant action, clearing free radicals derived from bacterial toxins produced by non-beneficial species, improving the intestinal environment and increasing motility as a result.

\section{Experimental Animal Study Methods}

The experimental method is as follows ${ }^{24} .204$-week-old ICR mice were raised in individual cages for one week and acclimatized. After acclimatization, the mice were weighed and sorted into the following 4 groups consisting of 5 mice each: ordinary diet (Group C), ordinary diet + astaxanthin (Group CA), high-fat diet (Group H), high fat diet + astaxanthin (Group HA).

Labo MR Stock (Nosan Corporation) was used for the ordinary diet, and HFD-60 Oriental Yeast Co.) for the high-fat diet. Both types of feed were prepared with added astaxanthin (Fuji Chemical Industry Co., Ltd.) to achieve a final concentration of $0.02 \%$. The nutritional contents of the ordinary diet consisted of $3.9 \%$ fat, $18.8 \%$ protein, $54.7 \%$ carbohydrates, and $6.6 \%$ dietary fiber; the high fat diet contained $35 \%$ fat, $23 \%$ protein, $25.3 \%$ carbohydrates, and $6.6 \%$ dietary fiber. Feces were collected over 24 hours on the final acclimatization day, hereafter designated Day 0 . The collected feces were stored at $-20^{\circ} \mathrm{C}$.

Fecal bacteria were tested using real-time PCR as follows. Feces collected on Days 0, 14, and 28 were thawed and weighed before drying overnight at room temperature. The following day, dry mass was weighed and samples were powderized. Approximately $100 \mathrm{mg}$ of each powdered sample was weighed into a microtest tube, and DNA was extracted using the QIAamp DNA Stool Mini Kit (Qiagen). DNA solutions were prepared and DNA concentration was measured using NanoDrop.

DNA solutions for total bacteria, Lactobacillus, Streptococcus, Clostridium coccoides group, and Clostridium leptum were diluted 100 times; other targets were adjusted to a final concentration of 20 $\mu \mathrm{g} / \mu \mathrm{L}$. Primer sequences were determined in accordance with the protocol for the LightCycler ${ }^{\circledR} 480$ SYBR Green I Master (Roche Diagnostics), and real-time PCR analysis was performed following the 
methods of Matsuki et al. or Endo et al. ${ }^{21-23}$ Bacteroides, Bifidobacterium, Prevotella, Lactobacillus, Clostridium Coccoides, and Clostridium leptum were targeted for analysis alongside two phyla, Firmicutes and Bacteroidetes, as well as total bacteria. The copy numbers of the targets were standardized as a percentage of total bacterial copies.

\section{Results of the Experimental Study}

\section{Change in body weight, feces color and quantity}

Mice administered the high-fat diet demonstrated a significant increase in weight $(\mathrm{p}<0.05)$ compared to ordinary diet groups (comparing $\mathrm{H}$ to $\mathrm{C}$, HA to $\mathrm{CA}$ ). No significant difference in weight was detected in the astaxanthin fed groups. The color of feces changed to a grayish white in the high-fat diet group mice, and became a wine red after the addition of astaxanthin. The amount of feces collected from the high-fat diet groups on Day 28 was significantly reduced ( $\mathrm{p}$ $<0.001)$.

\section{Fecal DNA Content}

The amounts of DNA recovered from feces as measured by NanoDrop (mean of Day 0, 14, 28) were: Group C: $89.8 \pm 21.5 \mathrm{ng} / \mu \mathrm{L}$; Group CA: $102.7 \pm 28.5 \mathrm{ng} / \mu \mathrm{L}$; Group H: $70.2 \pm 21.2 \mathrm{ng} / \mu \mathrm{L}$; Group HA: $66.9 \pm 28.4 \mathrm{ng} / \mu \mathrm{L}$. When compared to the ordinary diet groups (Group C and Group CA), the high-fat diet groups (Group H and Group HA) tended to have less DNA content $(\mathrm{p}=0.001)$.

\section{Genus Streptococcus (lactic acid bacteria)}

Streptococcus comprised less than $16 \%$ of the total bacterial count (Figure 1). The number of bacteria increased substantially in the ordinary diet, but the change was minor in the high-fat diet $(\mathrm{p}=0.028)$. Compared to the ordinary diet, the increase in bacteria in the high-fat diet group was extremely small $(p=0.008)$. With the addition of astaxanthin, the bacterial count of Group HA returned to the same level as the ordinary diet groups (Groups C and CA) on Day 28. The difference with and without astaxanthin in the high-fat diet groups was significant $(\mathrm{p}=0.044)$.

The genus Streptococcus is comprised of a variety of gram-positive and generally facultative anaerobic bacteria which belongs to the order Lactobacillales (lactic acid bacteria). While Streptococcus pneumoniae is a well-known pathogenic species (the leading cause of pneumonia), many other species are members of the salivary and gut microbiomes. At the genus level, depletion of Streptococcus has been observed in obese teenagers with high fructose intake ${ }^{26}$ and in children with celiac disease ${ }^{27}$. Conversely, Streptococcus is reported to increase in abundance in the guts of infants with a genetic predisposition for type 1 diabetes $^{28}$ as well as in colorectal cancer patients ${ }^{29}$. The seemingly contradictory implications of these different shifts in abundance may be due to the specific species which are falling out of balance in each situation.

On the species level, several bacteria are noted in the literature as potential probiotics. Streptococcus salivarius is an inhabitant of both the oral cavity and the gut: it has been demonstrated to possess anti-inflammatory and immuno-regulatory effects ${ }^{30,31}$. Streptococcus

\section{Genus Streptococcus}

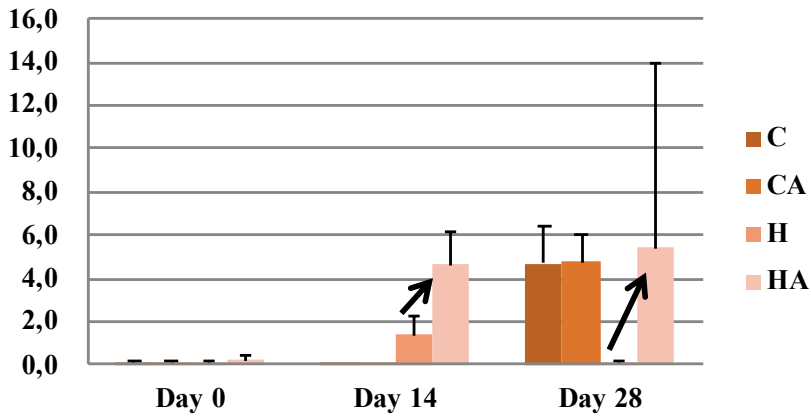

Figure 1. Putative copy numbers of the genus Streptococcus

Results shown as percent of total bacterial copy number, mean \pm standard deviation. C: ordinary diet group, CA: ordinary diet + astaxanthin group, $H$ : high-fat diet group, HA: high-fat diet + astaxanthin group, $(n=5$ each $)$. The addition of astaxanthin increased bacterial count in the high-fat diet group (indicated by arrows, $p<0.05$ ). Groups compared using Tukey's multiple comparison test. Cited from reference 24).

thermophilus, another probiotic species, may help to reduce uremic toxins caused by dysbiosis in the colon of patients with chronic kidney diseases ${ }^{32}$. As part of a probiotic cocktail together with other lactic acid bacteria (IRT5), S. thermophilus has shown efficacity in modulating auto-immunity ${ }^{33-35}$. By increasing the abundance of Streptococcus species, astaxanthin may contribute to maintaining the microbiome's homeostasis by promoting the proliferation of these beneficial bacteria.

\section{Genus Lactobacillus (lactic acid bacteria)}

Lactobacillus comprised less than 3\% of total bacterial copy numbers (Figure 2). Bacterial count was increased significantly in the high-fat diet group ( $p=0.004)$. The ordinary meal groups (groups $C$ and CA) also showed a trend of increasing bacterial count on days 14 and 28. There was no significant difference in the rate of bacterial count increase between the ordinary and high fat diets $(p=0.069)$. The rate of increase of bacterial count was shown to significantly increase with the addition of astaxanthin $(\mathrm{p}=0.031)$.

The genus Lactobacillus is widely known as a prominent member of the lactic acid bacteria and a common source of probiotics. As such, a large amount of research has focused on the beneficial effects of Lactobacillus species on gut health. In the early days of research into the human microbiomes, Lactobacillus was easily cultured from feces and mistakenly thought to constitute a majority of the gut microbiome $^{36}$. With the advent of genomic techniques to detect the countless species that are not easily cultivated in the lab (many of which are anaerobic), it was realized that Lactobacillus species are in actuality a small minority of the total biological diversity of the human gut, and many species are only transitory inhabitants that do not maintain a permanent presence in the intestinal tract. Despite this, the health effects of various Lactobacillus species have been heavily studied and numerous benefits have been reported.

Lactobacillus sakei has demonstrated efficacy in ameliorating obesity 


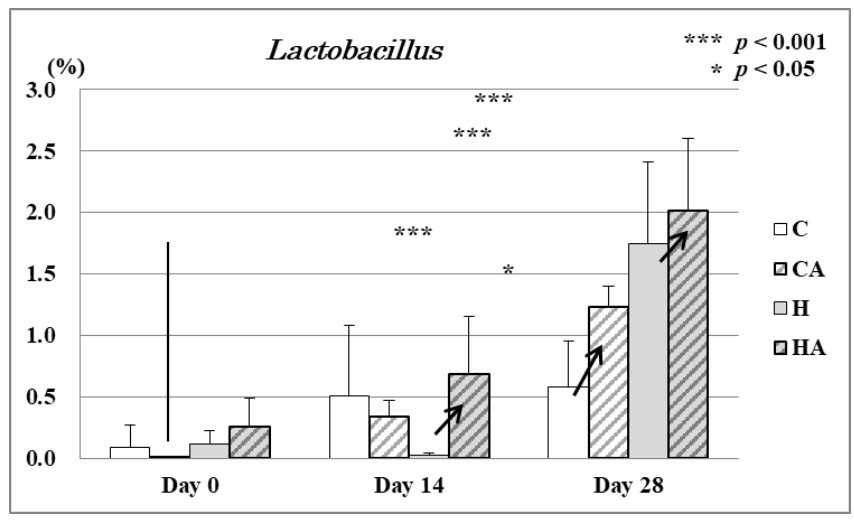

Figure 2. Putative copy numbers of the genus Lactobacillus

Results shown as percent of total bacterial copy number, mean \pm standard deviation. C: ordinary diet group, CA: ordinary diet + astaxanthin group, H: high-fat diet group, HA: high-fat diet + astaxanthin group, $(n=5$ each $)$. Addition of astaxanthin raised bacterial count (indicated by arrows, $p<0.05$ ). Groups compared using Tukey's multiple comparison test. Cited from reference 24).

caused by a high-fat diet in mouse model ${ }^{37,38}$. Mice fed L. sakei as a probiotic show reduced weight gain and lower serum levels of cholesterol, triglycerides, and leptin. Serum and fecal levels of short chain fatty acids are also increased after ingestion of L. sakei, counteracting the reduction seen in high-fat diets.

Lactobacillus plantarum has also been studied in mice fed high-fat $\operatorname{diets}^{39}$. When fed the probiotic, mice consuming a high-fat diet again experienced reduced weight gain and lower plasma levels of leptin, cholesterol, and triglycerides. It is also able to mitigate liver damage and weakened intestinal permeability of the intestines caused by obesity. Additionally, L. plantarum has been reported to increase the diversity of the enteric flora ${ }^{39,40}$, reduce the severity of colitis ${ }^{41,42}$, and it has also demonstrated anti-tumor effects ${ }^{43}$.

Lactobacillus rhamnosus has been shown to decrease the amount of colon aberrant crypt foci and reduce pro-carcinogenic biomarkers in a rat model ${ }^{44}$, lower cholesterol ${ }^{45}$, and improve insulin resistance and obesity induced by high-fat $\operatorname{diet}^{46}$.

Lactobacillus casei has demonstrated immunoregulatory activity, reducing colorectal cancer ${ }^{46}$ and breast tumors ${ }^{48}$ in mice models. Finally, Lactobacillus acidophilus has many reported beneficial effects. It has been found to improve gut dysbiosis, intestinal barrier function, and liver pathology in non-alcoholic fatty liver disease ${ }^{49}$. Like several of the previous species, it reduces high-fat diet induced obesity and improves insulin resistance ${ }^{46}$. It also demonstrates an anti-inflammatory effect, protecting mice from induced colitis ${ }^{50,51}$. In humans, L. acidophilus has been observed to be significantly reduced in the feces of type 2 diabetics ${ }^{52}$.

\section{Clostridium coccoides Group}

The Clostridium coccoides group contributed less than $1.4 \%$ of the total bacterial count (Figure 3). Bacterial count significantly increased from the high-fat diet $(\mathrm{p}=0.016)$. The increase was greater in the high-fat diet than the ordinary diet $(\mathrm{p}=0.012)$. The addition of astaxanthin was revealed to significantly lower the increase of bacteria

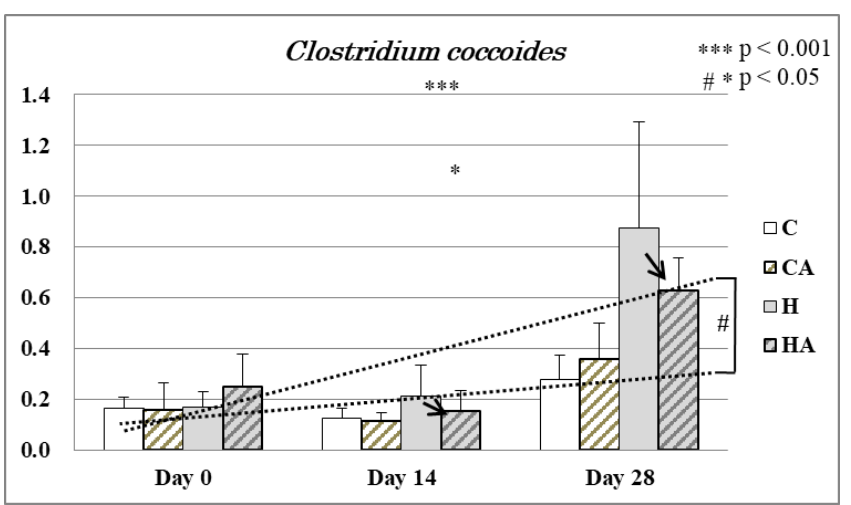

Figure 3. Putative copy numbers of the Clostridium coccoides group

Results shown as percent of total bacterial copy number, mean \pm standard deviation. C: ordinary diet group, CA: ordinary diet + astaxanthin group, $H$ : high-fat diet group, HA: high-fat diet + astaxanthin group, $(n=5$ each $)$. High-fat diet increased the rate of growth of bacterial count, (indicated by dotted lines), and addition of astaxanthin reduced it (indicated by arrows, $p<0.05$ ). Groups compared using Tukey's multiple comparison test, rate of change by diet compared using Mann-Whitney's $U$ test. Cited from reference 24$)$.

in the high-fat diet $(\mathrm{p}=0.029)$.

Clostridium is a major genus of anaerobic endo-spore forming bacteria $^{53}$. Several species in the genus are known pathogens, such as Clostridium botulinum (the causative pathogen of botulism), Clostridium tetani (tetanus) and former member Clostridium difficile (now Clostridioides difficile). Conversely, the Clostridium coccoides group also contains many bacteria that inhabit the human gut and play a considerable role in the intestinal ecosystem by fermenting dietary plant polysaccharides.

As a group, Clostridium has been reported to shift with age, becoming less abundant in the elderly ${ }^{53}$. This diminishing of Clostridium is associated with complications of aging such as frailty, hospitalization, and antibiotic treatment. However, Clostridium is also found to be elevated in the gut of children with type- 1 diabetes, and its abundance is positively correlated with plasma glucose levels ${ }^{54}$. Clostridium coccoides group is also significantly increased in the stool of obese individuals with metabolic syndrome and its abundance is correlated with higher serum levels of triglycerides ${ }^{55}$. Much like the genus Streptococcus, the effects of these shifts in abundance may differ depending on the specific species involved.

At the species level, Clostridium asparagiforme, Clostridium scindens, and Clostridium hylemonae are reported at high frequency in the elderly ${ }^{53}$. C. scindens and C. hylemonae exhibit bile-acid 7-dehydroxylating activity, producing secondary bile acids which are associated with the risk of developing gallstones and colon cancer. The Clostridium coccoides group also includes other anaerobic endo-spore forming bacteria of the human microbiome that are not necessarily taxonomically related to the genus Clostridium. Some Eubacterium species are also lumped into this group. These are commonly probiotic bacteria that are known for producing short-chain fatty acids such as butyrate, which exhibit anti-inflammatory and immuno-regulatory activity. Generally, Eubacterium abundance follows the opposite trend of the previously named Clostridium species, 
being reduced in abundance in the elderly ${ }^{53}$.

Depending on which species are involved, the results of changes in Clostridium abundance could be either beneficial or harmful. In the present study, Clostridium was found to increase during the high-fat diet, and was reduced toward normal levels by treatment with astaxanthin. Thus, the specific species affected may be those associated with dysbiosis caused by high fat intake, and not necessarily the beneficial varieties.

\section{Genus Bifidobacterium}

Bifidobacterium made up an extremely small amount of the total bacterial at less than $0.000006 \%$ (Figure 4 ). There was no significant difference between groups or before and after astaxanthin treatment. Since the standard deviation among individuals was so large, this result is only included for reference purposes.

Bifidobacterium is a genus of gram-positive anaerobic bacteria that is the first major colonizer of the human gastrointestinal tract and plays a significant role in maintaining intestinal health by preventing constipation, diarrhea, and colorectal cancer ${ }^{56}$. An abundance of the genus is closely correlated with the aging process ${ }^{57}$. Bifidobacterium colonizes newborns from birth and makes up a majority of infant microbiomes during their breast-feeding years, with species such as Bifidobacterium longum, B. breve, and B. bifidum being the most abundant. Their abundance falls to lower levels by adulthood (2-14\% of total bacteria), and is significantly reduced in the elderly. Low levels of Bifidobacterium are associated with obesity and diabetes (types 1 and 2$)^{54,57}$.

Bifidobacterium species have demonstrated numerous positive health effects and see common use as probiotics. B. longum and B. breve have both shown anti-obesity effects in a high-fat diet mouse model 58): oral intake of both species resulted in a reduction in weight gain, reduced triglyceride accumulation in the liver, and increased cecal abundance of lactic acid bacteria; B. longum intake additionally reduced serum triglycerides. Similar effects are seen in B. bifidum ${ }^{59}$ as well as various other strains ${ }^{60}$.

B. animalis subsp. lactis (AKA B. lactis), in addition to reducing weight gain, glycemic response, and fasting insulin levels in a high-fat diet mouse model, is also reported to reduce inflammation by downregulating tumor-necrosis factor expression in adipose and hepatic tissues ${ }^{61}$. B. lactis also mediates the effects of metabolic syndrome by improving glucose sensitivity, modulating the enteric flora, and producing a high amount of the short chain fatty-acid acetate ${ }^{62}$. Bifidobacterium may also impact anxiety and stress (via the gut-brain axis). In a mouse model of chronic stress, mice that were resistant to social stress from exposure to aggression had a higher abundance of Bifidobacterium, and intake of a probiotic containing B. longum and B. infantis increased resilience to stress and mitigated its symptoms $s^{63}$. B. bifidum has also been reported to reduce signs of stress in a maternal separation mouse model: mice ingesting the probiotic showed significantly reduced susceptibility to stress, with lower serum corticosterone and improved intestinal permeability ${ }^{64}$.

The lack of any observed change from astaxanthin intake in contrast

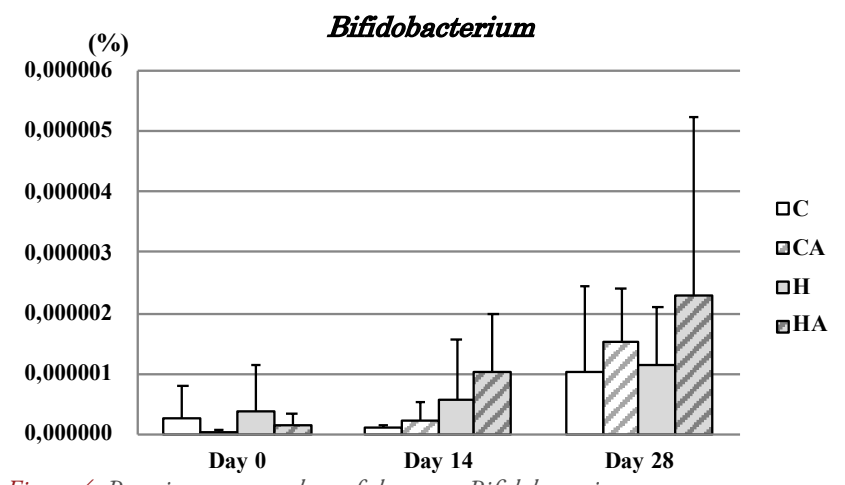

Figure 4. Putative copy numbers of the genus Bifidobacterium

Results shown as percent of total bacterial copy number, mean \pm standard deviation. C: ordinary diet group, CA: ordinary diet + astaxanthin group, $H$ : high-fat diet group, $H A$ : high-fat diet + astaxanthin group, $(n=5$ each $)$. Cited from reference 24).

to the other genera examined may simply be due to the very low initial abundance, or perhaps indicate that a difference in metabolic pathways of Bifidobacterium prevents the positive effect of the carotenoid on its physiology.

Other bacteria: Bacteroides, Prevotella, Clostridium leptum Of the total bacterial, Bacteroides comprised less than $0.003 \%$, a very small amount. The count was significantly increased by the high fat diet $(\mathrm{p}=0.006)$. Addition of astaxanthin resulted in no significant difference.

Prevotella copies were also few, at $0.06 \%$. The high fat diet markedly reduced bacterial count $(p<0.001)$. There was no significant change with the addition of astaxanthin.

Clostridium leptum copies comprised less than $1.6 \%$ of the total bacteria. It was significantly increased by the high fat diet $(\mathrm{p}=$ 0.017). There was no significant difference with astaxanthin.

\section{Phylum level analysis}

The results of phylum level analysis are represented as the ratios of Firmicutes, Bacteroidetes, and other copy numbers, as shown in Figure 5.

Firmicutes accounted for $20 \%$ of total copies on Day 0, but increased to $40 \%$ on both Day 14 and Day 28 in the high-fat diet group $(\mathrm{p}<0.001$, Figure 6$)$. There was no difference with the addition of astaxanthin.

Bacteroidetes made up 45 -50\% of total copies on Day 0, but fell to $20 \%$ on both Day 14 and Day 28 ( $p<0.001$ (Figure 7). There was no difference with the addition of astaxanthin.

Changes in enteric flora due to ingestion of High-FAT DieT Consumption of a high-fat diet increases the secretion of bile acids ${ }^{65}$, and causes various changes to the intestinal microbiota ${ }^{66}$. These changes are more pronounced in the large intestine than the small intestine $^{67}$. High-fat diets weaken intestinal immunity, disrupt mucosal barrier function, and cause abnormal fermentation to occur in the intestines $^{68}$. As a result, carcinogenesis is also increased ${ }^{69}$. 


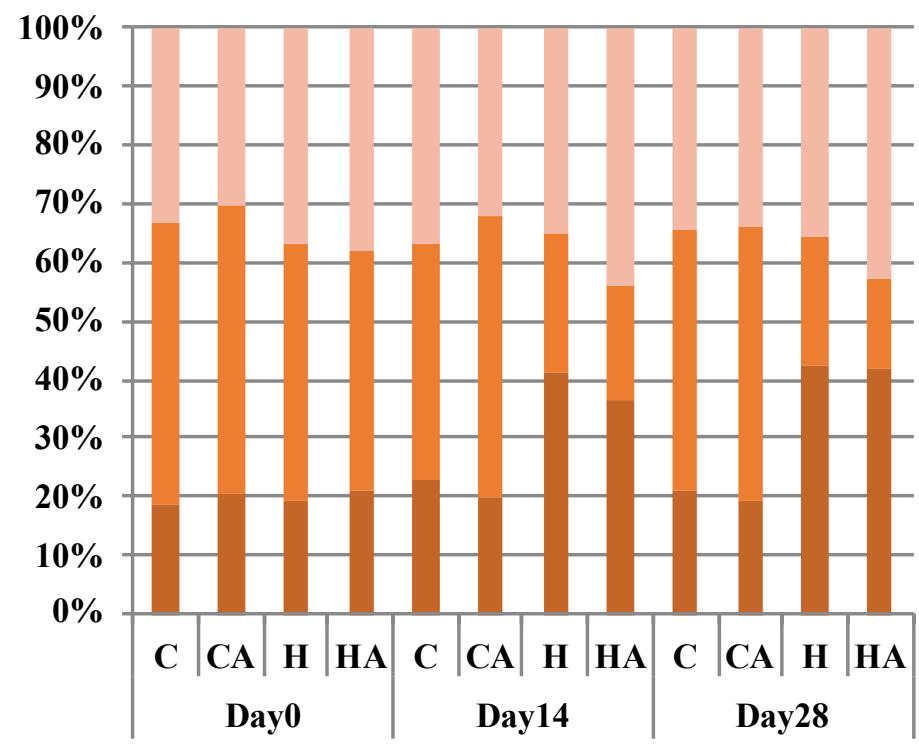

Others

\section{Bacteroidetes}

Firmicutes
Results pertaining to changes in gut microbiota caused by a high-fat diet have been reported in both animal and human studies. In a mouse model of type 2 diabetes (KK-Ay) Bacteroides is reduced and Clostridium coccoides tends to increase in the cecum ${ }^{70}$. In a mouse model of high-fat diet induced obesity, Bifidobacterium abundance in the cecum and feces was decreased ${ }^{71}$. In rats, Bacteroides and Prevotella were increased ${ }^{72}$. In humans, it has been reported that obese subjects likely consuming a high-fat diet carry a reduced amount of Bacteroides ${ }^{73}$. At the phylum level, Firmicutes have been

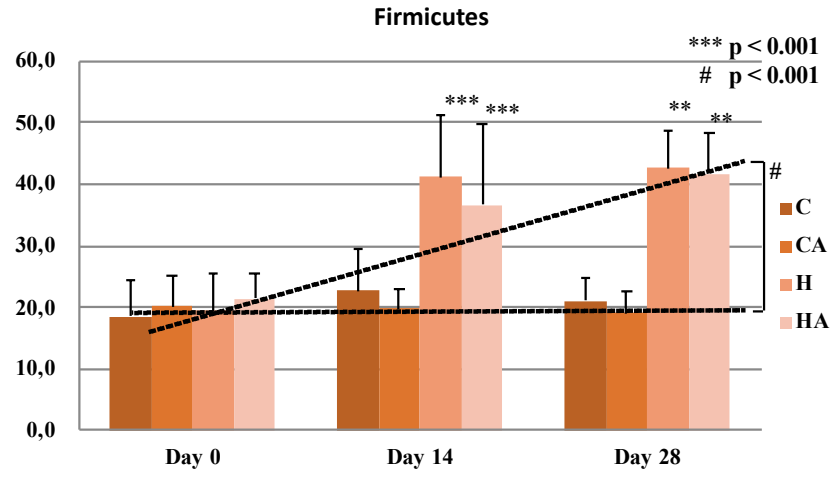

Figure 6. Putative copy number of the phylum Firmicutes

Results shown as percent of total bacterial copy number, mean \pm standard deviation. C: ordinary diet group, CA: ordinary diet + astaxanthin group, $H$ : high-fat diet group, HA: high-fat diet + astaxanthin group, $(n=5$ each $)$. Groups compared using Tukey's multiple comparison test (*** vs. Day 0 ), rate of change by diet compared using Mann-Whitney's U test (\#, dotted lines). Cited from reference 24).

found to increase while Bacteroidetes decrease $\mathrm{e}^{73-75}$.

In this study, the results of the phylum level analysis generally agreed with those previously reported ${ }^{73-75}$. Due to the high-fat diet (Group H), Bacteroides, Clostridium coccoides, and Clostridium leptum amounts increased, while Streptococcus (lactic acid bacteria) decreased. The difference in the change of Bacteroides may be due to differences between host animal (rat vs. mouse), or perhaps differences in testing methodology. However, Bacteroides species have previously been considered non-beneficial bacteria, so the results of the present study seem reliable.

\section{EFFECTS OF ASTAXANTHIN ON ENTERIC FLORA}

The following results regarding the effectiveness of astaxanthin were obtained from the animal study. First, astaxanthin can be expected to inhibit the short-term increase of Bacteroides (gram negative bacteria) caused by high-fat diet. Interestingly, the addition of astaxanthin increased the amount of Lactobacillus (lactic acid bacteria). Similarly, Streptococcus (lactic acid bacteria) was also increased by astaxanthin in the high fat diet. These results suggest that administering astaxanthin may improve enteric flora (inhibiting the overgrowth of gram-negative bacteria, increasing lactic acid bacteria).

For this experiment, astaxanthin was not administered via tube feeding, but instead a fixed amount $(0.02 \%$ astaxanthin) was mixed into

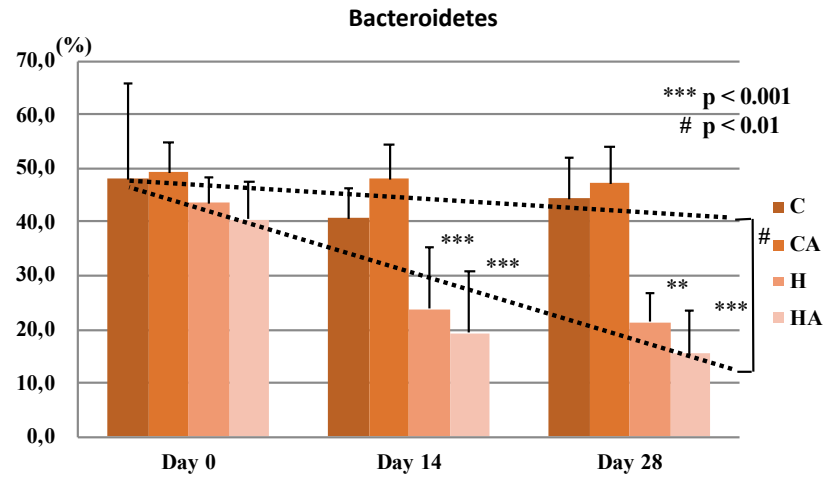

Figure 7. Putative copy numbers of the phylum Bacteroidetes Results shown as percent of total bacterial copy number, mean \pm standard deviation. C: ordinary diet group, CA: ordinary diet + astaxanthin group, $H$ : high-fat diet group, HA: high-fat diet + astaxanthin group, $(n=5$ each). Groups compared using Tukey's multiple comparison test (*** vs. Day 0 ), rate of change by diet compared using Mann-Whitney's U test (\#, dotted lines). Cited from reference 24).

the mice's feed. While tube feeding would have allowed for more consistency in dosage, the resulting damage to the upper gastrointestinal tract and increased stress on the mice would likely affect the intestinal microbiota. Individual differences were also increased: with mixed feed the dosage of astaxanthin depends on feed intake and is not a fixed quantity, however there is little stress on the mice.

Astaxanthin intake was estimated from the feed intake of the mice (mean body weight at 8 weeks: Group C 38 41 g, Group H 44 48 g). The feed intake of Group $\mathrm{C}$ mice was about $3 \mathrm{~g} /$ day, consisting of $0.2 \mathrm{~g} /$ day of fat, $0.9 \mathrm{~g} /$ day of protein, and $1.0 \mathrm{mg} /$ day of astaxanthin per mouse. The group $\mathrm{H}$ mice received about $5 \mathrm{~g} /$ day of feed consisting of $1.1 \mathrm{~g} /$ day of fat, $0.7 \mathrm{~g} /$ day of protein, and $0.6 \mathrm{mg} /$ day of astaxanthin. The equivalent intake of astaxanthin for a human (average body weight $60 \mathrm{~kg}$ ) would be $1,500 \mathrm{mg} /$ day for group CA 
and $800 \mathrm{mg} /$ day for group HA, significantly higher than the typical supplement amounts of 6-24 mg/day. Thus, from this experiment it is not clear whether such an amount is suitable for human intake. Approximately 95\% of the astaxanthin remains in the intestinal tract unabsorbed. Less than $5 \%$ is absorbed and enters systemic circulation, only some of which reaches the digestive tract again. Therefore, the majority of the astaxanthin likely acts directly on the intestinal microbiota. Any action by the astaxanthin on the intestinal tract or intestinal immunity has not yet been reported.

\section{ConcLusion}

The various bacterial cells that live in the human gut and form the intestinal microbiome number in the range of 600 trillion, 10 times the number of native cells that make up the human body itself. The makeup of the enteric flora shifts not only with age, but also due to diet, exercise, alcohol intake, smoking, and other lifestyle/environmental factors. These changes play a role in health, contributing to things such as obesity, skin conditions, atopy, allergies, and carcinogenesis. In order to maintain a youthful and healthy body, it is crucial to protect the health and stability of the enteric flora. Modern diets have led to an increase in the consumption of fats in recent years, and the resulting changes to the intestinal microbiota have been report$\mathrm{ed}^{70,71,76,77}$. Mitigating these changes is of great importance.

The mechanism by which astaxanthin prevented changes to the bacterial flora from a high-fat diet could not be determined within the scope of the presented studies. However, the following potential mechanisms are proposed:

1. It is possible that the antioxidant action of astaxanthin exerted a beneficial effect on the enteric flora. The change in bacterial composition induced by the high-fat diet, particularly the growth of gram-negative bacteria, created higher levels of oxidative stress. As astaxanthin intake improved the enteric flora, the increased oxidative stress may have been mitigated. This needs to be confirmed.

2. Astaxanthin may be degraded by bacteria, producing low molecular weight substances which may then be responsible for the beneficial changes to the enteric flora in high-fat diets. It is necessary to examine the metabolic pathways of astaxanthin in the intestinal tract.

3. Astaxanthin or its metabolites may have an effect on intestinal immunity. Markers related to intestinal immunity (e.g. IgA, defensin) need to be examined.

The intestinal tract of every individual is inhabited by an assortment of characteristic bacteria, which collectively form the enteric microbiome. When fat intake increases due to changes in diet, the equilibrium between the various species that constitute the intestinal flora is altered. As a result, degenerative changes in lifestyle-related disease and aging of the host are promoted. Here we find that the intake of astaxanthin was able to inhibit these changes in the gut microbiota of mice induced by a high-fat diet. Even in humans, it is highly probably that the unabsorbed astaxanthin that remains in the intestinal tract exerts a positive effect against disturbance of the intestinal flora caused by a high-fat diet.

\section{AUTHOR CONTRIBUTIONS:}

All authors listed have made a substantial, direct and intellectual contribution to the work, and approved it for publication.

\section{LITERATURE:}

1. Ambati RR, Phang SM, Ravi S, et al. Astaxanthin: Sources, extraction, stability, biological activities and its commercial applications: A review. Mar Drugs. 2014;12(1):128-152. doi: 10.3390/ md12010128.

2. Yuan JP, Peng J, Yin K, et al. Potential health-promoting effects of astaxanthin: A high-value carotenoid mostly from microalgae. Mol Nutr Food Res. 2011;55(1):150-165. doi: 10.1002/mnfr.201000414. 3. Wolf AM, Asoh S, Hiranuma H, et al. Astaxanthin protects mitochondrial redox state and functional integrity against oxidative stress. J Nutr Biochem. 2010;21(5):381-389. doi: 10.1016/j.jnutbio.2009.01.011.

4. Naguib YM. Antioxidant activities of astaxanthin and related carotenoids. J Agric Food Chem. 2000;48(4):1150-1154.

5. Iwabayashi M, Fujioka N, Nomoto K, et al. Efficacy and safety of eight-week treatment with astaxanthin in individuals screened for increased oxidative stress burden. Anti-Aging Med. 2009;6(4):15-21. doi: 10.3793/jaam.6.15.

6. Odeberg JM, Lignell Å, Pettersson A, et al. Oral bioavailability of the antioxidant astaxanthin in humans is enhanced by incorporation of lipid based formulations. Eur J Pharm Sci. 2003;19:299-304. doi: 10.1016/S0928-0987(03)00135-0.

7. Okada Y, Ishikura M, Maoka T. Bioavailability of astaxanthin in
Haematococcus algal extract: The effects of timing of diet and smoking habits. Biosci Biotechnol Biochem. 2009;73(9):1928-1932.

8. Meor Mohd Affandi MMR, Julianto T, Majeed ABA. Enhanced oral bioavailability of astaxanthin with droplet size reduction. Food Sci. Technol. Res. 2012;18(4):549-554.

9. Nagpal R, Mainali R, Ahmadi S, et al. Gut microbiome and aging: Physiological and mechanistic insights. Nutr Healthy Aging. 2018;4(4):267-285. doi: 10.3233/NHA-170030.

10. Odamaki T, Kato K, Sugahara H, et al. Age-related changes in gut microbiota composition from newborn to centenarian: A cross-sectional study. BMC Microbiology. 2016;16(90).

11. DeGruttola AK, Low D, Mizoguchi A, et al. Current understanding of dysbiosis in disease in human and animal models. Inflamm Bowel Dis. 2016;22(5):1137-1150. doi:10.1097/ MIB.0000000000000750.

12. Bodogai M, O'Connell J, Kim K, et al. Commensal bacteria contribute to insulin resistance in aging by activating innate B1a cells. Sci Transl Med. 2018;10(467):eaat4271. doi:10.1126/scitranslmed. aat 4271 .

13. Gentile CL, Weir TL. The gut microbiota at the intersection of diet and human health. Science. 2018;362(6416):776-780. doi: $10.1126 /$ science.aau5812.

14. Wilson ID, Nicholson JK. Gut microbiome interactions with drug 
metabolism, efficacy, and toxicity. Transl Res. 2017;179:204-222. doi: $10.1016 / j . t r s l .2016 .08 .002$.

15. Zimmermann M, Zimmermann-Kogadeeva M, Wegmann R, et al. Mapping human microbiome drug metabolism by gut bacteria and their genes. Nature. 2019;570(7762):462-467. doi: 10.1038/s41586019-1291-3.

16. Gérard C, Vidal H. Impact of gut microbiota on host glycemic control. Front Endocrinol (Lausanne). 2019;10:29. doi: 10.3389/ fendo.2019.00029.

17. Lazar V, Ditu LM, Pircalabioru GG, et al. Aspects of gut microbiota and immune system interactions in infectious diseases, immunopathology, and cancer. Front Immunol. 2018;9:1830. doi: 10.3389/ fimmu.2018.01830.

18. Alexander JL, Scott AJ, Pouncey AL, et al. Colorectal carcinogenesis: An archetype of gut microbiota-host interaction. Ecancermedicalscience. 2018;12:865. doi: 10.3332/ecancer.2018.865.

19. Rea D, Coppola G, Palma G, et al. Microbiota effects on cancer: From risks to therapies. Oncotarget. 2018;9(25):17915-17927. doi: 10.18632/oncotarget. 24681

20. Vivarelli S, Salemi R, Candido S, et al. Gut microbiota and cancer: From pathogenesis to therapy. Cancers (Basel). 2019;11(1):38. doi: $10.3390 /$ cancers 11010038

21. Matsuki T, Watanabe K, Fujimoto J, et al. Use of $16 \mathrm{~S}$ rRNA gene-targeted group-specific primers for real-time PCR analysis of predominant bacteria in human feces. Appl Environ Microbiol. 2004;70(12):7220-7228. doi: 10.1128/AEM.70.12.72207228.2004

22. Matsuki T, Watanabe K, Fujimoto J, et al. Development of $16 \mathrm{~S}$ rRNA-gene-targeted group-specific primers for the detection and identification of predominant bacteria in human feces. Appl Environ Microbiol. 2002;68(11):5445-5451. doi: 10.1128/aem.68.11.54455451.2002

23. Endo A, Okada S, Morita H. Molecular profiling of Lactobacillus, Streptococcus, and Bifidobacterium species in feces of active racehorses. J Gen Appl Microbiol. 2007;53(3):191-200.

24. Yonei Y, Yagi M, Nakamura M, et al. Effects of astaxanthin on intestinal microflora in mice fed a high-fat diet. Anti-Aging Med. 2013;10(4):77-91.

25. Oguma Y, Iida K, Yonei Y, et al. Significance evaluation of Anti-Aging QOL Common Questionnaire. Glycative Stress Res. 2016;3(3):177-185. doi: 10.24659/gsr.3.3_177

26. Jones RB, Alderete TL, Kim JS, et al. High intake of dietary fructose in overweight/obese teenagers associated with depletion of Eubacterium and Streptococcus in gut microbiome. Gut Microbes. 2019:1-8. doi: 10.1080/19490976.2019.1592420.

27. Sánchez E, Donat E, Ribes-Koninckx C, et al. Duodenal-mucosal bacteria associated with celiac disease in children. Appl Environ Microbiol. 2013;79(18):5472-5479. doi: 10.1128/AEM.00869-13. 28. Kostic AD, Gevers D, Siljander H, et al. The dynamics of the human infant gut microbiome in development and in progression toward type 1 diabetes. Cell Host Microbe. 2015;17(2):260-273. doi: 10.1016/j.chom.2015.01.001.

29. Wang T, Cai G, Qiu Y, et al. Structural segregation of gut microbiota between colorectal cancer patients and healthy volunteers. ISME J. 2012;6(2):320-329. doi: 10.1038/ismej.2011.109.

30. Cosseau C, Devine DA, Dullaghan E, et al. The commensal Streptococcus salivarius $\mathrm{K} 12$ downregulates the innate immune responses of human epithelial cells and promotes host-microbe homeostasis. Infect Immun. 2008;76(9):4163-4175. doi: 10.1128/IAI.00188-08. 31. Kaci G, Goudercourt D, Dennin V, et al. Anti-inflammatory properties of Streptococcus salivarius, a commensal bacterium of the oral cavity and digestive tract. Appl Environ Microbiol.
2014;80(3):928-934. doi: 10.1128/AEM.03133-13.

32. Vitetta L, Llewellyn H, Oldfield D. Gut dysbiosis and the intestinal microbiome: Streptococcus thermophilus, a key probiotic for reducing uremia. Microorganisms. 2019;7(8):228. doi: 10.3390/ microorganisms 7080228 .

33. Chae CS, Kwon HK, Hwang JS, et al. Prophylactic effect of probiotics on the development of experimental autoimmune myasthenia gravis. PLoS One. 2012;7(12):e52119. doi: 10.1371/journal. pone.0052119.

34. Kim J, Choi SH, Kim YJ, et al. Clinical effect of IRT-5 probiotics on immune modulation of autoimmunity or alloimmunity in the eye. Nutrients. 2017;9(11):1166. doi: 10.3390/nu9111166

35. Kwon HK, Kim GC, Kim Y, et al. Amelioration of experimental autoimmune encephalomyelitis by probiotic mixture is mediated by a shift in Thelper cell immune response. Clin Immunol. 2013;146(3):217-227. doi: 10.1016/j.clim.2013.01.001.

36. Walter J. Ecological role of lactobacilli in the gastrointestinal tract: Implications for fundamental and biomedical research. Appl Environ Microbiol. 2008;74(16):4985-4996. doi: 10.1128/AEM.0075308.

37. Jang HM, Han SK, Kim JK, et al. Lactobacillus sakei alleviates high-fat-diet-induced obesity and anxiety in mice by inducing AMPK activation and SIRT1 expression and inhibiting gut microbiota-mediated NF- $\bigotimes$ B activation. Mol Nutr Food Res. 2019 Mar;63(6):e1800978. doi: 10.1002/mnfr.201800978.

38. Ji Y, Park S, Chung Y, et al. Amelioration of obesity-related biomarkers by Lactobacillus sakei CJLS03 in a high-fat diet-induced obese murine model. Sci Rep. 2019;9(1):6821. doi: 10.1038/s41598019-43092-y.

39. Wu CC, Weng WL, Lai WL, et al. Effect of Lactobacillus plantarum strain K21 on high-fat diet-fed obese mice. Evid Based Complement Alternat Med. 2015;2015:391767. doi: 10.1155/2015/391767 40. Linninge $\mathrm{C}, \mathrm{Xu}$ J, Bahl MI, et al. Lactobacillus fermentum and Lactobacillus plantarum increased gut microbiota diversity and functionality, and mitigated Enterobacteriaceae, in a mouse model. Benef Microbes. 2019;10(4):413-424. doi: 10.3920/BM2018.0074.

41. Zhang F, Li Y, Wang X, et al. The impact of Lactobacillus plantarum on the gut microbiota of mice with DSS-induced colitis. Biomed Res Int. 2019;2019:3921315. doi: 10.1155/2019/3921315 42. Trabelsi I, Ktari N, Ben Slima S, et al. Effect of a probiotic Lactobacillus plantarum TN8 strain on trinitrobenzene sulphonic acid-induced colitis in rats. J Anim Physiol Anim Nutr (Berl). 2017;101(2):311-319. doi: 10.1111/jpn. 12536

43. Hu J, Wang C, Ye L, et al. Anti-tumour immune effect of oral administration of Lactobacillus plantarum to CT26 tumour-bearing mice. J Biosci. 2015;40(2):269-79.

44. Gamallat Y, Ren X, Wallana W, et al. Probiotic Lactobacillus rhamnosus modulates the gut microbiome composition attenuates preneoplastic colorectal Aberrant crypt foci. Journal of Functional Foods. 2019;53:146-156. doi: 10.1016/j.jff.2018.12.018.

45. Park S, Kang J, Choi S, et al. Cholesterol-lowering effect of Lactobacillus rhamnosus BFE5264 and its influence on the gut microbiome and propionate level in a murine model. PLoS One. 2018;13(8):e0203150. doi: 10.1371/journal.pone.0203150.

46. Bagarolli RA, Tobar N, Oliveira AG, et al. Probiotics modulate gut microbiota and improve insulin sensitivity in DIO mice. J Nutr Biochem. 2017;50:16-25. doi: 10.1016/j.jnutbio.2017.08.006 47. Lenoir M, Del Carmen S, Cortes-Perez NG, et al. Lactobacillus casei BL23 regulates Treg and Th17 T-cell populations and reduces DMH-associated colorectal cancer. J Gastroenterol. 2016;51(9):862873. doi: $10.1007 / \mathrm{s} 00535-015-1158-9$.

48. Aragón F, Carino S, Perdigón G, et al. The administration of 
milk fermented by the probiotic Lactobacillus casei CRL 431 exerts an immunomodulatory effect against a breast tumour in a mouse model. Immunobiology. 2014;219(6):457-64. doi: 10.1016/j.imbio.2014.02.005.

49. Xue L, He J, Gao N, et al. Probiotics may delay the progression of nonalcoholic fatty liver disease by restoring the gut microbiota structure and improving intestinal endotoxemia. Sci Rep. 2017;7:45176. doi: $10.1038 /$ srep 45176 .

50. Chen L, Zou Y, Peng J, et al. Lactobacillus acidophilus suppresses colitis-associated activation of the IL-23/Th17 axis. J Immunol Res. 2015;2015:909514. doi: 10.1155/2015/909514.

51. Park JS, Choi JW, Jhun J, et al. Lactobacillus acidophilus improves intestinal inflammation in an acute colitis mouse model by regulation of Th17 and Treg cell balance and fibrosis development. J Med Food. 2018;21(3):215-224. doi: 10.1089/jmf.2017.3990.

52. Halawa MR, El-Salam MA, Mostafa BM, et al. The gut microbiome, Lactobacillus acidophilus; Relation with type 2 diabetes mellitus. Curr Diabetes Rev. 2019;15(6):480-485. doi: 10.2174/15733998156 66190206162143.

53. Kurakawa T, Ogata K, Matsuda K, et al. Diversity of intestinal Clostridium coccoides group in the Japanese population, as demonstrated by reverse transcription-quantitative PCR. PLoS One. 2015;10(5):e0126226. doi: 10.1371/journal.pone.0126226.

54. Murri M, Leiva I, Gomez-Zumaquero JM, et al. Gut microbiota in children with type 1 diabetes differs from that in healthy children: A case-control study. BMC Med. 2013;11:46. doi:10.1186/1741-7015$11-46$.

55. Jamar G, Santamarina AB, Dias GC, et al. Relationship between fatty acids intake and Clostridium coccoides in obese individuals with metabolic syndrome. Food Res Int. 2018;113:86-92.N.D.

56. O'Callaghan A, van Sinderen D. Bifidobacteria and their role as members of the human gut microbiota. Front Microbiol. 2016;7:925. doi: $10.3389 /$ fmicb.2016.00925.

57. Arboleya S, Watkins C, Stanton C, et al. Gut Bifidobacteria populations in human health and aging. Front Microbiol. 2016;7:1204. doi: $10.3389 /$ fmicb.2016.01204.

58. Alsharafani M, Roderfeld M, Roeb E, et al. Bifidobacterium breve M4A and Bifidobacterium longum subsps. longum FA1 reduced weight gain and hepatic lipid droplets in young mice fed high-fat. J Prob Health. 2016;4:3. doi: 10.4172/2329-8901.1000152. 59. Li Z, Jin H, Oh SY, et al. Anti-obese effects of two Lactobacilli and two Bifidobacteria on ICR mice fed on a high fat diet. Biochem Biophys Res Commun. 2016;480(2):222-227. doi: 10.1016/j. bbrc.2016.10.031.

60. Yin YN, Yu QF, Fu N, et al. Effects of four Bifidobacteria on obesity in high-fat diet induced rats. World J Gastroenterol. 2010;16(27):3394-3401. doi: 10.3748/wjg.v16.i27.3394.

61. Wang J, Tang H, Zhang C, et al. Modulation of gut microbiota during probiotic-mediated attenuation of metabolic syndrome in high fat diet-fed mice. ISME J. 2015;9:1-15. doi: 10.1038/ismej.2014.99. 62. Aoki R, Kamikado K, Suda W, et al. A proliferative probiotic Bifidobacterium strain in the gut ameliorates progression of metabolic disorders via microbiota modulation and acetate elevation. Sci Rep. 2017;7:43522. doi: 10.1038/srep43522.
63. Yang C, Fujita Y, Ren Q, et al. Bifidobacterium in the gut microbiota confer resilience to chronic social defeat stress in mice. Sci Rep. 2017;7:45942. doi: 10.1038/srep45942.

64. Fukui H, Oshima T, Tanaka Y, et al. Effect of probiotic Bifidobacterium bifidum G9-1 on the relationship between gut microbiota profile and stress sensitivity in maternally separated rats. Sci Rep. 2018;8:12384. doi: 10.1038/s41598-018-30943-3.

65. Nigro ND, Campbell RL, Singh DV, et al. Effect of diet high in beef fat on the composition of fecal bile acids during intestinal carcinogenesis in the rat. J Natl Cancer Inst. 1976;57(4):883-888.

66. Cani PD, Delzenne NM, Amar J, et al. Role of gut microflora in the development of obesity and insulin resistance following high-fat diet feeding. Pathol Biol (Paris). 2008;56(5):305-309. doi: 10.1016/j. patbio.2007.09.008.

67. Steegenga WT, de Wit NJ, Boekschoten MV, et al. Structural, functional and molecular analysis of the effects of aging in the small intestine and colon of C57BL/6J mice. BMC Med Genomics. 2012;5:38. doi: 10.1186/1755-8794-5-38

68. Okazaki Y, Tomotake H, Tsujimoto K, et al. Consumption of a resistant protein, sericin, elevates fecal immunoglobulin $\mathrm{A}$, mucins, and cecal organic acids in rats fed a high-fat diet. J Nutr. 2011 Nov;141(11):1975-1981. doi: 10.3945/jn.111.144246.

69. Cummings JH, Wiggins HS, Jenkins DJ, et al. Influence of diets high and low in animal fat on bowel habit, gastrointestinal transit time, fecal microflora, bile acid, and fat excretion. J Clin Invest. 1978;61(4):953-963.

70. Kitano Y, Murazumi K, Duan J, et al. Effect of dietary porphyran from the red alga, Porphyra yezoensis, on glucose metabolism in diabetic KK-Ay mice. J Nutr Sci Vitaminol (Tokyo). 2012;58(1):14-19.

71. Kondo S, Xiao JZ, Satoh T, et al. Antiobesity effects of Bifidobacterium breve strain B-3 supplementation in a mouse model with high-fat diet-induced obesity. Biosci Biotechnol Biochem. 2010;74(8):1656-1661.

72. Mozes S, Bujnáková D, Sefcíková Z, et al. Developmental changes of gut microflora and enzyme activity in rat pups exposed to fatrich diet. Obesity (Silver Spring). 2008 Dec;16(12):2610-2615. doi: 10.1038/oby.2008.435.

73. DiBaise JK, Zhang H, Crowell MD, et al. Gut microbiota and its possible relationship with obesity. Mayo Clin Proc. 2008;83(4):460469. doi: $10.4065 / 83.4 .460$.

74. Sefcíková Z, Kmet V, Bujnáková D, et al. Development of gut microflora in obese and lean rats. Folia Microbiol (Praha). 2010;55(4):373-375. doi: 10.1007/s12223-010-0061-2.

75. Kim KA, Gu W, Lee IA, et al. High fat diet-induced gut microbiota exacerbates inflammation and obesity in mice via the TLR4 signaling pathway. PLoS One. 2012;7(10):e47713. doi: 10.1371/journal.pone. 0047713 .

76. Macfarlane GT, Macfarlane S. Diet and metabolism of the intestinal flora. Bioscience Microflora: Bioscience and Microflora. 2002;21(4):199-208. doi: 10.12938/bifidus1996.21.199.

77. Yokota A, Fukiya S, Islam KB, et al. Is bile acid a determinant of the gut microbiota on a high-fat diet? Gut Microbes. 2012;3(5):455459. 